BMJ Paediatrics Open

\title{
Evidence that informs feeding practices in very low birthweight and very preterm infants in sub-Saharan Africa: an overview of systematic reviews
}

Abimbola Akindolire, ${ }^{1}$ Alison Talbert (D) , ${ }^{2}$ Ian Sinha, ${ }^{3}$ Nicholas Embleton (D) , Stephen Allen, ${ }^{5}$ on behalf of the Neonatal Nutrition Network (NeoNuNet)

\section{ABSTRACT}

Background Optimal feeding of very low birthweight (VLBW $<1500 \mathrm{~g}$ )/very preterm (gestation $<32$ weeks) infants in resource-limited settings in sub-Saharan Africa (SSA) is critical to reducing high mortality and poor outcomes.

Objective To review evidence on feeding of VLBW/very preterm infants relevant to SSA.

Methods We searched the Cochrane Database of Systematic Reviews, Embase, PubMed and Cumulative Index to Nursing and Allied Health Literature (CINAHL) from inception to July 2019 to identify reviews of randomised and quasi-randomised controlled trials of feeding VLBW/very preterm infants. We focused on interventions that are readily available in SSA. Primary outcomes were weight gain during hospital stay and time to achieve full enteral feeds (120 $\mathrm{mL} / \mathrm{kg} / \mathrm{day}$ ). Secondary outcomes were growth, common

AA and AT are joint first authors.

Received 4 May 2020

Revised 19 June 2020

Accepted 23 June 2020

\section{Check for updates}

(c) Author(s) (or their employer(s)) 2020. Re-use permitted under CC BY. Published by BMJ.

${ }^{1}$ College of Medicine, University of Ibadan, Ibadan, Oyo, Nigeria ${ }^{2}$ Clinical Research, KEMRIWellcome Trust Research Programme, Kilifi, Kenya ${ }^{3}$ Respiratory Medicine, Alder Hey Children's NHS Foundation Trust, Liverpool, UK

${ }^{4}$ Neonatal medicine, Newcastle University, Newcastle upon

Tyne, UK

${ }^{5}$ Paediatrics, Liverpool School of Tropical Medicine, Liverpool, UK

Correspondence to Dr Alison Talbert; ATalbert@ kemri-wellcome.org morbidities, mortality, duration of hospital stay and cognitive development. Quality of evidence (QOE) was assessed using the Measurement Tool to Assess Systematic Reviews

Results Eight systematic reviews were included. Higher feed volume of day $1(80 \mathrm{~mL} / \mathrm{kg})$ reduced late-onset sepsis and time to full enteral feeds, and higher feed volume (up to $300 \mathrm{~mL} / \mathrm{kg} /$ day) improved weight gain without adverse events (QOE: low-moderate). Rapid advancement of feeds (30-40 mL/kg/day) was not associated with harm. Breast milk fortification with energy and protein increased growth and with prebiotics increased growth and reduced duration of admission (QOE: low-very low) and did not result in harm. Evidence regarding feeding tube placement and continuous versus bolus feeds was insufficient to draw conclusions. We found no reviews meeting our selection criteria regarding when to start feeds, use of preterm formula, cup-and-spoon feeding or gravity versus push feeds and none of the reviews included trials from low-income countries of SSA.

Conclusions The evidence base informing feeding of VLBW/very preterm babies in resource-limited settings in sSA is extremely limited. Pragmatic studies are needed to generate evidence to guide management and improve outcomes for these highly vulnerable infants.

PROSPERO registration number CRD42019140204.

\section{BACKGROUND}

Worldwide about 15 million babies are born preterm annually and it is estimated that $28 \%$ of these births occur in sub-Saharan Africa (AMSTAR2).

\section{What is known about the subject?}

Although survival is improving, mortality and outcomes for very low birthweight (VLBW)/very preterm infants in resource-limited settings in sub-Saharan Africa (SSA) remain poor.

- Optimising feeding is critical to improving survival, healthy growth and development and reducing morbidity.

- International and national protocols inform the feeding of VLBW/very preterm infants but evidence relevant to resource-limited settings is limited.

\section{What this study adds?}

No trials of pragmatic feeding interventions have been conducted in resource-limited settings in SSA.

- Higher feed volumes, rapid advancement of feeds and fortification of breast milk may be beneficial in achieving full feeds, improving growth and reducing morbidity without adverse effects.

- Trials of pragmatic feeding protocols in resourcelimited settings are needed urgently to better inform clinical practice.

(sSA). ${ }^{1}$ An increasing number of very low birthweight (VLBW; BW $<1500 \mathrm{~g}$ ) babies are surviving till discharge in low/middle-income countries (LMICs). ${ }^{2}$ Optimal nutrition is key for survival, prevention of adverse events such as sepsis and reducing the length of the hospital stay. ${ }^{3}$ In addition, there is strong evidence that early nutrition impacts on multiorgan developmental patterning, immune, cardiac and respiratory function and longer term cognitive outcome as well as a range of chronic conditions such as diabetes and cardiovascular disease in adulthood which place a substantial burden on healthcare systems. ${ }^{3-7}$

Most very preterm infants (gestation $<32$ weeks) have yet to develop coordinated oromotor skills of sucking, swallowing and 
breathing that allow safe breast feeding and, therefore, other methods of feeding are necessary. Uncertainty about gestational age due to a lack of reliable first trimester ultrasound scan is common in LMICs and birth weight is often used to identify infants who are preterm, growth retarded or both. ${ }^{8}$ In most neonatal units in LMICs, parenteral nutrition is not available. ${ }^{9}$ Trials on enteral feeding interventions have been done mainly in high-income and middle-income countries. The generalisability of their findings to feeding VLBW infants in most of sSA is difficult to assess due to multiple differences in maternal, pregnancy, delivery, neonatal and environmental factors and also the levels of care and clinical monitoring provided in high-income versus LMICs. ${ }^{10-12}$

Although internationally agreed guidelines on optimal feeding of low birthweight infants in LMICs, including some recommendations for VLBW infants, were published by the WHO in 2011, these lacked a strong evidence base especially for LMIC settings. ${ }^{9}$ This led us to search the literature for evidence from reviews of studies conducted in, or applicable to, sSA. The aim of our study was to review the evidence for pragmatic, low-cost interventions to optimise the feeding of VLBW/very preterm infants in low-resource settings in sSA. We systematically searched for evidence on when to start enteral feeds; how to advance feeds; what to feed when mother's own milk is insufficient or not available and how to feed.

\section{METHODS AND ANALYSIS}

\section{Protocol registration}

We registered the overview protocol prospectively on the PROSPERO International Prospective Register of Systematic Reviews (http://www.crd.york.ac.uk/PROSPERO/display_record.php?ID=CRD42019140204).

\section{Patient and public involvement}

There was no patient or public involvement in the planning or execution of this overview.

\section{Search strategy}

We searched the Cochrane Database of Systematic Reviews, Embase, PubMed and CINAHL from inception to July 2019 for systematic reviews and meta-analyses of randomised controlled trials (RCTs) that assessed the key questions listed above irrespective of language of publication. The key search terms were: very low birthweight or preterm AND (enteral feeding or enteral nutrition) AND (systematic review or meta-analysis). We checked the reference lists of the identified articles and published guidelines for systematic reviews not previously identified.

\section{Selection of reviews}

Criteria for inclusion of reviews are shown in box 1 . Reviews reporting interventions not currently widely available in sSA, such as use of donor breast milk, ${ }^{13}$ transpyloric feeding ${ }^{14}$ and specific nutritional supplements, ${ }^{15-17}$

\section{Box 1 Criteria for inclusion of reviews}

Participants
Neonates (babies aged $<28$ days)
Birth weight less $<1500 \mathrm{~g}$ and/or gestation $<32$ weeks
Interventions
When to start enteral feeds:
- Age $<24$ hours or $\geq 24$ hours
How to advance feeds:
- Slow (15-20 mL/kg/day) versus fast (30-35 mL/kg/day)
What to feed when mother's milk is insufficient or not available:
- Preterm formula versus standard infant formula
- Unfortified versus fortified breastmilk
How to feed:
- Nasogastric versus orogastric tube versus cup and spoon feeding
- Continuous versus bolus feeds
- Gravity versus push feeds
Interventions not currently widely available in sSA were excluded.
Outcomes
- Primary outcomes
- Weight gain during hospital stay (g/kg/day or time to regain birth
$\quad$ weight)
- Time in days to achieve full enteral feeds (120 mL/kg/day)
- Secondary outcomes
- Gain in length and head circumference during hospital stay
- Frequency of necrotising enterocolitis, sepsis
- Duration of hospital stay in days
- Cognitive development
- Mortality

were excluded. Two authors independently screened titles and abstracts to identify relevant reviews for fulltext review. Disagreements were resolved by discussion involving a third author.

\section{Data extraction and management}

One author extracted data from all selected reviews into a spreadsheet (Microsoft Excel) including number and settings of the included trials, total number and characteristics of participants, intervention(s) assessed, outcomes measured and major limitations. A second author crosschecked the extracted data for accuracy.

\section{Assessment of methodological quality of included reviews}

Two authors independently assessed the quality of each review using the revised AMSTAR 2 (A Measurement Tool to Assess systematic Reviews) tool. ${ }^{18}$ Discrepancies were resolved by discussion and, if necessary, arbitration by a third author. The level of confidence in the findings of the reviews was assessed according to the number of critical and minor flaws in the methodology. ${ }^{18}$ 


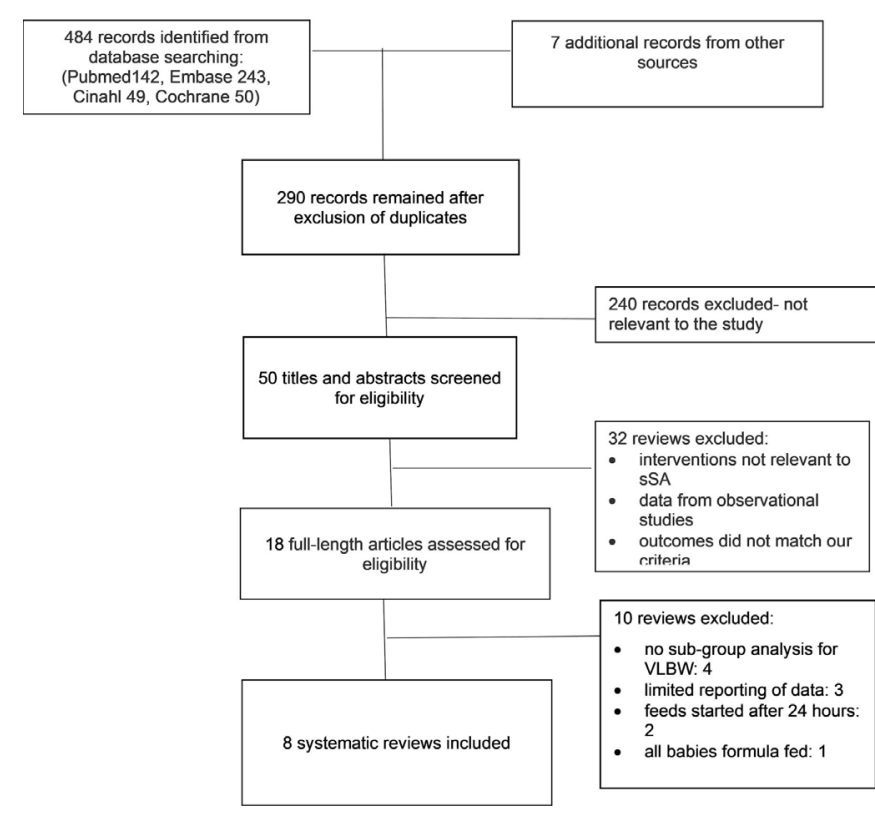

Figure 1 Flow diagram of selection of reviews. sSA, subSaharan Africa; VLBW, very low birth weight.

\section{Outcomes}

Primary outcomes were weight gain during hospital stay and time to achieve full enteral feeds (120 mL/ $\mathrm{kg} /$ day). These were selected on the basis that they are recorded routinely in LMIC settings and are directly relevant to clinical practice. Secondary outcomes included growth, other important clinical outcomes such as sepsis, necrotising enterocolitis (NEC), death, duration of hospital stay and cognitive development (box 1).

\section{Data synthesis}

We presented the findings for the primary and secondary outcomes for each intervention. ${ }^{19}$ We reported other outcome data in a narrative form. The relevance of the findings to feeding VLBW/very preterm infants in sSA was evaluated.

\section{Patient and public involvement}

Patients and/or the public were not involved in the design, or conduct, or reporting, or dissemination plans of this research.

\section{RESULTS}

The search yielded 491 reviews (figure 1). After excluding duplicate and updated reviews, the titles and abstracts of 50 reviews were assessed for inclusion. The full texts of 18 reviews were screened of which 10 were excluded (see online supplementary file 1). Eight reviews met our inclusion criteria (table 1). The number of studies included in reviews ranged from 1 to 14 and the number of participants from 14 to 3753 . Some of the findings from studies were pooled in a meta-analysis in four reviews. ${ }^{20-23}$ None of the reviews included studies from low-income countries including in sSA. Table 2 summarises the outcomes measured and estimates of size of effects of each intervention.

\section{When to start feeds}

We did not find any reviews comparing the effects of starting feeds before or after 24 hours of life.

\section{How to advance enteral feeds}

One review that assessed increasing feeds up to $300 \mathrm{~mL} /$ $\mathrm{kg} /$ day versus $200 \mathrm{~mL} / \mathrm{kg} /$ day included 1 study which recruited 64 babies. Weight gain was greater in the highvolume group with no increase in feeding intolerance, NEC or mortality. The authors assessed the quality of evidence as low to very low because of heterogeneity and risk of bias due to lack of blinding. ${ }^{24}$

One review assessed daily increments of less than 24 $\mathrm{mL} / \mathrm{kg}$ compared with $30-40 \mathrm{~mL} / \mathrm{kg}$. There were 10 studies with a total of 3753 participants. Rate of feed advancement was not associated with weight gain, frequency of NEC or mortality. Slow advancement of feeds may have resulted in a longer time to achieve full feeds, longer hospital stay and a higher risk of sepsis. The authors downgraded the quality of evidence to moderate because there was a lack of blinding in most studies. ${ }^{22}$

One review that assessed advancing feeds to $80 \mathrm{~mL} / \mathrm{kg}$ by the end of the first day compared with $20-30 \mathrm{~mL} / \mathrm{kg}$ included 4 randomised trials and a total of 393 babies. ${ }^{23}$ In clinically stable babies, those who had higher volume feeds had lower rates of late-onset sepsis and shorter time to full enteral feeds; these effects were statistically significant in meta-analysis and there was no significant heterogeneity. Higher volume feeds also reduced time to regain birth weight but with significant heterogeneity between the trials. Only two trials reported duration of hospital stay and these trials had significant heterogeneity. The quality of the evidence from the trials was rated as 2 to 3 (low to adequate) on the Jadad scale.

\section{What to feed when mother's milk is insufficient or not available}

There were no reviews comparing the effect of preterm versus standard term formula.

One review that assessed the effect of fortification of human milk with both energy and protein included 14 trials (13 RCTs and one quasi-RCT) and a total of 1071 participants. ${ }^{20}$ Meta-analysis showed a higher weight, length and head circumference at discharge, 12 and 18 months in the fortified group. There was no significant effect on neurodevelopment, NEC, feed intolerance or length of hospital stay. The review authors downgraded the quality of evidence to low as there was significant heterogeneity possibly due to the use of different feeds: some studies used mother's milk only, some mother's milk and donor milk (when mother's milk was insufficient) and others mother's milk and formula.

A systematic review assessed the effect of addition of fat to human milk feeds. The review included 1 study with only 14 babies; there was no evidence that the addition of fat improved in-hospital growth or affected tolerance of feeds. ${ }^{25}$ The quality of evidence was very low due to 
Table 1 Characteristics of included reviews

\begin{tabular}{|c|c|c|c|c|}
\hline Review & Population & Intervention arm & Comparison arm & Outcomes reported \\
\hline \multicolumn{5}{|c|}{ 1. How to advance feeds } \\
\hline Abiramalatha et $a l^{24}$ & $\begin{array}{l}\text { Preterm ( }<37 \text { weeks) or } \\
\text { low birthweight }(<2500 \\
\text { g) infants }\end{array}$ & $\begin{array}{l}\text { High volume enteral } \\
\text { feeds up to } 300 \mathrm{~mL} / \mathrm{kg} / \\
\text { day }\end{array}$ & $\begin{array}{l}\text { Standard volume } \\
\text { enteral feeds } \leq 200 \mathrm{~mL} \\
\mathrm{~kg} / \text { day }\end{array}$ & $\begin{array}{l}\text { Weight gain during } \\
\text { hospital stay } \\
\text { Feed intolerance } \\
\text { Necrotising } \\
\text { enterocolitis }\end{array}$ \\
\hline Oddie et $\left.a\right|^{22}$ & $\begin{array}{l}\text { Enterally fed very } \\
\text { preterm (<32 weeks) or } \\
\text { VLBW infants }\end{array}$ & $\begin{array}{l}\text { Faster advancement of } \\
\text { enteral feeds }\end{array}$ & $\begin{array}{l}\text { Advancement of enteral } \\
\text { feeds no faster than } 24 \\
\mathrm{~mL} / \mathrm{kg} \text { (birth weight or } \\
\text { current weight) per day }\end{array}$ & $\begin{array}{l}\text { Feed intolerance } \\
\text { Time to establish full } \\
\text { enteral feeding } \\
\text { Incidence of invasive } \\
\text { infections } \\
\text { Necrotising } \\
\text { enterocolitis } \\
\text { Duration of hospital } \\
\text { stay } \\
\text { Mortality }\end{array}$ \\
\hline Alshaikh et $a l^{23}$ & $\begin{array}{l}\text { VLBW (1000 to }<1500 \\
\text { g) stable newborn } \\
\text { infants }\end{array}$ & $\begin{array}{l}\text { Enteral feeds started on } \\
\text { day } 1 \text { at } 80 \mathrm{~mL} / \mathrm{kg} / \text { day } \\
\text { and increased by } 20 \\
\mathrm{~mL} / \mathrm{kg} / \text { day }\end{array}$ & $\begin{array}{l}\text { Enteral feeds started on } \\
\text { day } 1 \text { at } \leq 30 \mathrm{~mL} / \mathrm{kg} / \text { day } \\
\text { and increased by } 20 \\
\mathrm{~mL} / \mathrm{kg} / \text { day }\end{array}$ & $\begin{array}{l}\text { Time to regain birth } \\
\text { weight } \\
\text { Feed intolerance: time } \\
\text { to establish full enteral } \\
\text { feeds. } \\
\text { Necrotising } \\
\text { enterocolitis and } \\
\text { sepsis } \\
\text { Duration of hospital } \\
\text { stay }\end{array}$ \\
\hline
\end{tabular}

2.What to feed

Brown et $a^{20} \quad$ Preterm ( $<37$ weeks) and low birthweight (<2500 g) infants receiving breast milk in hospital
Fortification of breast milk with energy (carbohydrate or fat) and protein. Fortifiers could additionally include micronutrients and vitamins
Breast milk not fortified with energy or protein but can receive micronutrients and vitamins
Growth: weight, length, head circumference

- Length of hospital stay

- Feed intolerance

- Necrotising enterocolitis

- Bone mineralisation: serum alkaline phosphatase, bone mineral content

- Neurodevelopmental outcomes at 18 months: mental development index and psychomotor development index

\begin{tabular}{|c|c|c|c|c|}
\hline Amissah et $a l^{25}$ & $\begin{array}{l}\text { Preterm (<37 weeks) } \\
\text { infants receiving enteral } \\
\text { feeding of human milk } \\
\text { in hospital }\end{array}$ & $\begin{array}{l}\text { Human milk with } \\
\text { additional fat } \\
\text { supplementation }\end{array}$ & $\begin{array}{l}\text { Human milk without } \\
\text { additional fat } \\
\text { supplementation }\end{array}$ & $\begin{array}{l}\text { Growth: weight, } \\
\text { length, head } \\
\text { circumference }\end{array}$ \\
\hline Amissah et al ${ }^{26}$ & $\begin{array}{l}\text { Preterm (<37 weeks) } \\
\text { infants receiving human } \\
\text { milk in hospital }\end{array}$ & $\begin{array}{l}\text { Human milk with } \\
\text { additional carbohydrate } \\
\text { supplementation }\end{array}$ & $\begin{array}{l}\text { Human milk without } \\
\text { additional carbohydrate } \\
\text { supplementation }\end{array}$ & $\begin{array}{l}\text { Weight at day } 30 \text { of } \\
\text { age } \\
\text { Duration of hospital } \\
\text { stay } \\
\text { Feed intolerance } \\
\text { Necrotising } \\
\text { enterocolitis }\end{array}$ \\
\hline
\end{tabular}


Table 1 Continued

\begin{tabular}{|c|c|c|c|c|}
\hline Review & Population & Intervention arm & Comparison arm & Outcomes reported \\
\hline \multicolumn{5}{|l|}{ 3. How to feed } \\
\hline Watson et $a l^{27}$ & $\begin{array}{l}\text { Preterm ( }<37 \text { weeks) or } \\
\text { low birthweight }(<2500 \\
\text { g) infants receiving tube } \\
\text { feeding }\end{array}$ & $\begin{array}{l}\text { Nasal placement of } \\
\text { feeding tubes }\end{array}$ & $\begin{array}{l}\text { Oral placement of } \\
\text { feeding tubes }\end{array}$ & $\begin{array}{l}\text { Time to establish full } \\
\text { tube feeds } \\
\text { Time to regain birth } \\
\text { weight } \\
\text { Weight gain } \\
\text { Time to independence } \\
\text { from supplemental } \\
\text { oxygen }\end{array}$ \\
\hline Premji and Chessell ${ }^{21}$ & $\begin{array}{l}\text { VLBW infants with no } \\
\text { history of feeding or } \\
\text { feed intolerance and no } \\
\text { congenital anomalies } \\
\text { that might interfere with } \\
\text { establishing enteral } \\
\text { feeds }\end{array}$ & $\begin{array}{l}\text { Continuous nasogastric } \\
\text { feeding with human } \\
\text { milk or infant formula }\end{array}$ & $\begin{array}{l}\text { Intermittent bolus } \\
\text { nasogastric feeding } \\
\text { with human milk or } \\
\text { infant formula }\end{array}$ & $\begin{array}{l}\text { Time to establish full } \\
\text { enteral feeds } \\
\text { Time to establish full } \\
\text { oral feeds } \\
\text { Feed intolerance } \\
\text { Days on TPN } \\
\text { Time to regain birth } \\
\text { weight } \\
\text { Growth: weight, } \\
\text { length, head } \\
\text { circumference, triceps } \\
\text { skinfold thickness } \\
\text { Duration of hospital } \\
\text { stay } \\
\text { Days to discharge } \\
\text { weight of } 2040 \mathrm{~g} \\
\text { Days on mechanical } \\
\text { ventilation } \\
\text { Proven or probable } \\
\text { necrotising } \\
\text { enterocolitis } \\
\text { Failure to complete } \\
\text { protocol due to feed } \\
\text { intolerance } \\
\text { Apnoea }\end{array}$ \\
\hline
\end{tabular}

TPN, total parenteral nutrition; VLBW, very low birth weight $(<1500 \mathrm{~g})$.

incomplete description of the methodology and small sample size.

A review that assessed the effect of supplementation of human milk with short-chain galacto-oligosaccharides/ long-chain fructo-oligosaccharides included 1 study with 75 participants. There was a significant increase in weight in the supplemented group and decrease in the length of hospital stay but no effect on the incidence of NEC or sepsis. ${ }^{26}$ The review authors downgraded the quality of evidence to very low because of a significant risk of bias and the uncertainty resulting from the small sample size.

\section{How to feed}

Nasogastric versus orogastric tube versus cup and spoon feeding A review that assessed nasal versus oral placement of enteral feeding tubes and included 1 RCT with 46 infants found insufficient evidence that the placement of enteral feeding tubes affected time to full enteral feeds, growth and feed intolerance. The review authors assessed the quality of evidence as low due to lack of blinding and failure to report all important outcomes. ${ }^{27}$ There was no review assessing cup and spoon feeding in VLBW babies.

\section{Continuous versus bolus feeds}

One review that assessed continuous nasogastric versus intermittent bolus feeds included 7 trials and 511 babies. There were no significant differences in growth, length of hospital stay or incidence of NEC. The review authors concluded that the benefits and risks of continuous and intermittent feeding could not be assessed from current RCTs and called for future studies to be conducted with consistent feeding protocols and definitions of feed intolerance. $^{21}$

\section{Gravity versus push feeds}

We found no reviews assessing gravity versus push feeds.

\section{Methodological quality of the included reviews}

We have reported the AMSTAR2 assessments in table 3. 
Table 2 Findings from systematic reviews

\begin{tabular}{llll} 
Review/outcome & No of studies (no of babies) & $\begin{array}{l}\text { Results } \\
\text { MD or RR }(95 \% \mathrm{Cl})\end{array}$ & $\begin{array}{l}\text { Quality of evidence } \\
\text { (GRADE assessment) }\end{array}$ \\
\hline
\end{tabular}

1. How to advance feeds

Abiramalatha et $a^{24}$ : high volume versus standard volume feeds

\begin{tabular}{|c|c|c|c|}
\hline Weight gain (g/kg/day) & $1(64)$ & MD 6.2 (2.71 to 9.69) & Low \\
\hline Frequency of NEC & $1(64)$ & RR 1.03 (0.07 to 15.78$)$ & Very low \\
\hline Feed intolerance & $1(64)$ & RR 1.81 (0.89 to 3.67$)$ & Low \\
\hline Mortality & $1(64)$ & No death in any group & NR \\
\hline \multicolumn{4}{|c|}{ Oddie et $a^{22}$ : slow versus faster rate or few advancement } \\
\hline Weight gain at discharge & $1(2804)$ & MD $0.0(-0.08$ to 0.08$)$ & NR \\
\hline Time to full feeds & $8(3551)$ & $\begin{array}{l}\text { Longer time in slow } \\
\text { advancement group. CI NR }\end{array}$ & NR \\
\hline $\begin{array}{l}\text { Gain in Head Circumference } \\
\text { (HC) z score at discharge }\end{array}$ & $1(2804)$ & MD $0.0(-0.13$ to 0.13$)$ & NR \\
\hline Frequency of NEC & $10(3738)$ & RR 1.07 (Cl 0.83 to 1.39$)$ & Moderate \\
\hline Frequency of sepsis & $8(3391)$ & RR 1.15 (1.00 to 1.32$)$ & Low \\
\hline Duration of hospital stay in day & & $\begin{array}{l}2 \text { trials reported longer } \\
\text { duration in slow } \\
\text { advancement group }\end{array}$ & NR \\
\hline Mortality & $9(3553)$ & RR 1.15 (0.93 to 1.42$)$ & Moderate \\
\hline \multicolumn{4}{|c|}{ Alshaikh et al ${ }^{23}$ : early total enteral feeds versus early partial enteral feeds } \\
\hline Time to regain birth weight & $2(149)$ & $\begin{array}{l}\text { MD }-1.15 \text { days }(-1.86 \text { to } \\
-0.45)\end{array}$ & Moderate (Jadad score) \\
\hline Feed intolerance & $3(347)$ & RR 0.78 (0.38 to 1.59$)$ & Moderate (Jadad score) \\
\hline Time to full enteral feeds & $2(164)$ & $\begin{array}{l}\text { MD }-1.01 \text { days }(-1.36 \text { to } \\
-0.66)\end{array}$ & Moderate (Jadad score) \\
\hline Frequency of NEC & $4(393)$ & RR 0.87 (0.19 to 3.98 ) & Moderate (Jadad score) \\
\hline Incidence of late onset sepsis & $3(290)$ & RR 0.43 (0.30 to 0.61$)$ & Moderate (Jadad score) \\
\hline Duration of hospital stay & $4(393)$ & $\begin{array}{l}\mathrm{MD}-1.35 \text { days }(-2.57 \text { to } \\
-0.13)\end{array}$ & Moderate (Jadad score) \\
\hline
\end{tabular}

2. What to feed

Brown et $a^{20}$ : breast milk fortified with carbohydrate, fat and protein versus unfortified breast milk

\begin{tabular}{llll} 
Weight gain $(\mathrm{g} / \mathrm{kg} /$ day $)$ & $5(269)$ & MD $2.82(1.83$ to 3.80$)$ & Low \\
\hline Gain in length $(\mathrm{cm} / \mathrm{wk})$ & $3(189)$ & MD $0.21(0.14$ to 0.28$)$ & Low \\
\hline Gain in $\mathrm{HC}(\mathrm{cm} / \mathrm{wk})$ & $3(189)$ & $\mathrm{MD} 0.11(0.05$ to 0.17$)$ & Moderate \\
\hline $\begin{array}{l}\text { Frequency of NEC } \\
\text { Feed intolerance }\end{array}$ & $7(539)$ & RR $1.19(0.49$ to 2.88$)$ & Low \\
$\begin{array}{l}\text { Duration of hospital stay in } \\
\text { weeks }\end{array}$ & $5(255)$ & RR $0.90(0.54$ to 1.49$)$ & Low \\
\hline
\end{tabular}

Amissah et $a^{25}$ : breast milk supplemented with fat versus unsupplemented breast milk

\begin{tabular}{|c|c|c|c|}
\hline Weight gain (g/kg/day) & $1(14)$ & MD $0.60(-2.4$ to 3.6$)$ & Very low \\
\hline Length gain $(\mathrm{cm} / \mathrm{wk})$ & $1(14)$ & MD $0.10(-0.08$ to 0.3$)$ & Very low \\
\hline $\begin{array}{l}\text { Head circumference gain }(\mathrm{cm} / \\
\text { wk) }\end{array}$ & $1(14)$ & MD $0.2(-0.07$ to 0.4$)$ & Very low \\
\hline Feed intolerance & $1(16)$ & RR 3.0 (0.1 to 64.3$)$ & Very low \\
\hline \multicolumn{4}{|c|}{ Amissah et $a^{26}$ : breast milk supplemented with prebiotic carbohydrate versus unsupplemented breast milk } \\
\hline Weight gain at age 30 days $(\mathrm{g})$ & $1(75)$ & MD 160.4 (12.4 to 308.4$)$ & Very low \\
\hline Frequency of NEC & $1(75)$ & RR 0.2 (0.02 to 1.3$)$ & Very low \\
\hline
\end{tabular}


Table 2 Continued

\begin{tabular}{lcll}
\hline Review/outcome & No of studies (no of babies) & $\begin{array}{l}\text { Results } \\
\text { MD or RR (95\% Cl) }\end{array}$ & $\begin{array}{l}\text { Quality of evidence } \\
\text { (GRADE assessment) }\end{array}$ \\
\hline Duration of hospital stay in days & $1(75)$ & $\begin{array}{l}\text { Median (range) supplement } \\
\text { versus control: } 16 \text { (9 to 45) }\end{array}$ & Very low \\
& & versus 25 (11 to 80$) p=0.004$
\end{tabular}

\begin{tabular}{|c|c|c|c|}
\hline \multicolumn{4}{|l|}{ 3. How to feed } \\
\hline \multicolumn{4}{|c|}{ Watson and McGuire ${ }^{27}$ : nasal versus oral placement of feeding tube } \\
\hline $\begin{array}{l}\text { Time to regain birth weight in } \\
\text { days }\end{array}$ & $1(46)$ & MD $0.90(-1.27$ to 3.07$)$ & $\begin{array}{l}\text { NR 'Study underpowered } \\
\text { to exclude modest but } \\
\text { plausible effect sizes' }\end{array}$ \\
\hline Time to full feeds (days) & $1(46)$ & $\mathrm{MD}-2.7(-11.9$ to 6.5$)$ & NR \\
\hline \multicolumn{4}{|c|}{ Premii and Chesse $\mathbb{I}^{21}$ : continuous nasogastric milk versus intermittent bolus feeds } \\
\hline Weight gain (g/wk) & $2(106)$ & MD $6.27(-1.28$ to 13.81$)$ & NR \\
\hline $\begin{array}{l}\text { Time to regain birth weight in } \\
\text { days }\end{array}$ & $3(206)$ & MD $-0.31(-1.65$ to 1.03$)$ & NR \\
\hline Time to full feeds in days & 4 (229) & MD $1.82(-0.44$ to 4.08$)$ & NR \\
\hline Gain in length $(\mathrm{cm} / \mathrm{wk})$ & $3(159)$ & MD $0.07(-0.04$ to 0.18$)$ & NR \\
\hline Gain in $\mathrm{HC}(\mathrm{cm} / \mathrm{wk})$ & $2(77)$ & MD $-0.01(-0.12$ to 0.13$)$ & NR \\
\hline Frequency of proven NEC & $4(270)$ & RR 2.23 (0.58 to 8.57 ) & NR \\
\hline Duration of hospital stay in days & $1(82)$ & $M D-1.00(-8.62$ to 6.62$)$ & NR \\
\hline
\end{tabular}

GRADE, Grading of Recommendation Assessment Development and Evaluation; MD, mean difference; NEC, necrotising enterocolitis; NR, not reported.

PICO components regarding the research questions and inclusion criteria $(\mathrm{Q} 1)$ were stated in all reviews. Only two reviews stated clearly that the review methods had been established prior to the conduct of the review and justified any significant deviations in methodology where appropriate. ${ }^{25}$ Although standard Cochrane methodology includes publication of a protocol (Q2) and assessment of the likelihood and impact of publication bias (Q15), we downgraded our quality assessment for Cochrane reviews if these elements were not reported. Methods for searching the literature (Q4), selecting studies for inclusion (Q5), extracting data (Q6) and assessing risk of bias (Q9) were done well in all studies. Only one study reported on the sources of funding for the studies $(\mathrm{Q} 10) .{ }^{26}$ All reviews except one ${ }^{25}$ reported potential sources of conlfict of interest. The only review that was not a Cochrane review had several methodological flaws which led to a critically low level of confidence in its findings. ${ }^{23}$ Overall, our confidence in the findings of the reviews was critically low in 1 , moderate in 6 and high in only 1.

\section{DISCUSSION}

This overview demonstrates that there is a severe lack of evidence to inform basic feeding practices in this highly vulnerable group of infants in low-resource settings in sSA. We found evidence supporting starting feeds at a higher volume, faster advancement of feeds, fortification of breast milk with energy and protein or prebiotics.
However, we found only eight systematic reviews which included small numbers of trials, some of which had few participants. Quality of evidence as assessed by the review authors ranged from very low to moderate. An inherent difficulty in evaluating some feeding approaches is blinding of trial arms. Furthermore, our confidence in the findings was high for only one review. No reviews of RCTs in VLBW babies assessed important issues such as the use of preterm formula, cup and spoon feeding and gravity versus push feeds. Finally, none of the reviews included trials done in the low-income countries of sSA.

The strengths of this review are that it collates the evidence of RCTs of feeding interventions for highly vulnerable newborns that are feasible in low-resource settings. It appraises the quality of reviews using a validated measure (AMSTAR2) and updates and expands on the findings of the evidence review commissioned by the WHO published in $2011 .^{9}$ A weakness in our review of the evidence that informs feeding practices is that we limited our search to systematic reviews and have not considered other forms of evidence such as RCTs not included in reviews.

Human donor milk has been recommended by the WHO as the best alternative when mother's own milk is not available but there are few human milk banks operating in sSA. ${ }^{9}$ The practice of wet nursing and informal milk sharing has been carried out in many societies in Africa but we did not find any systematic reviews in hospital settings. In recent years, these practices have 


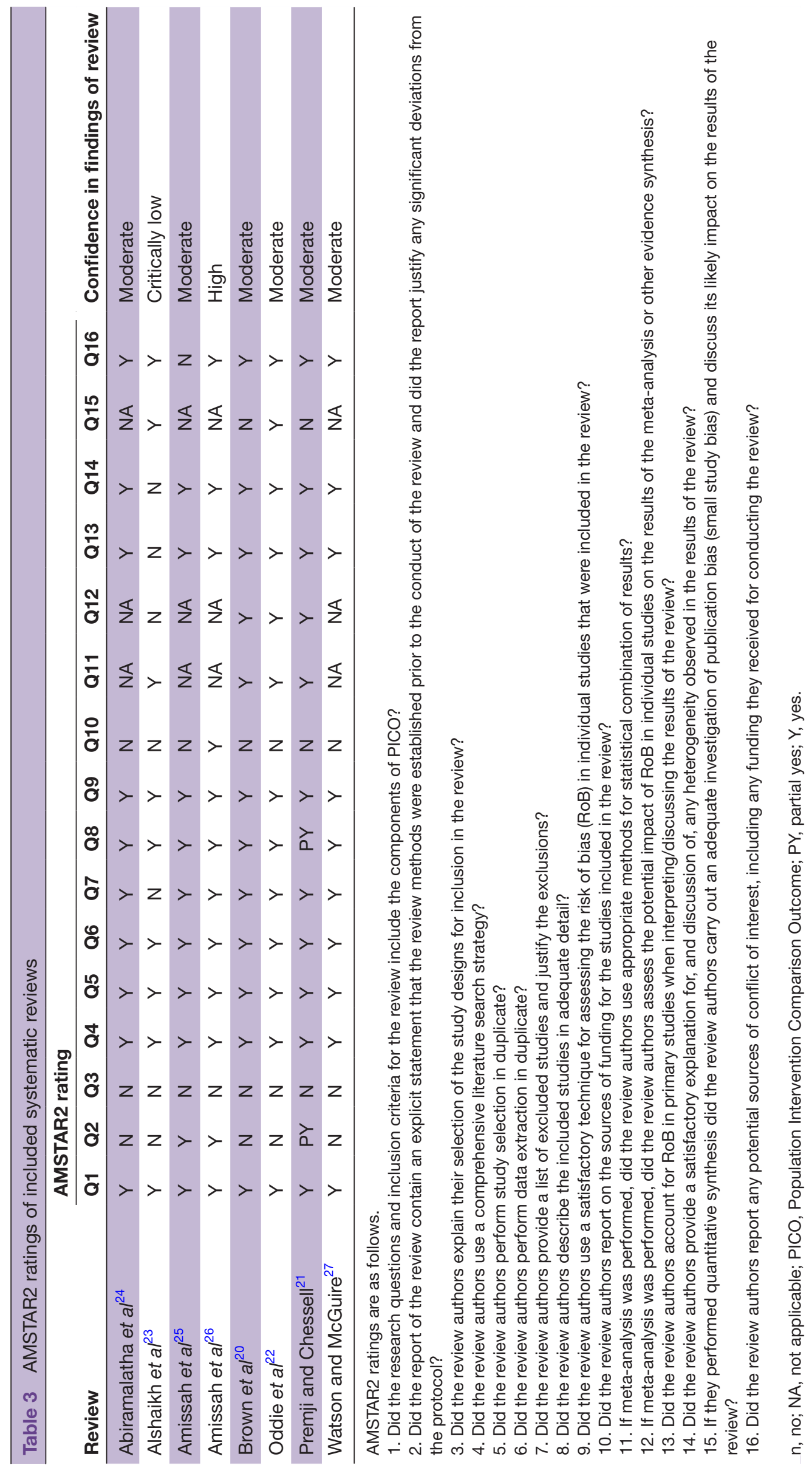


been discouraged due to fears of HIV transmission but qualitative studies in sSA have explored parents' and healthcare workers' attitudes to using screened and pasteurised donor human milk through facility-based human milk banks. ${ }^{28} 29$

Low-income countries lack resources to provide parenteral nutrition to VLBW/very preterm babies, particularly in the public health facilities. Hence, the focus is on achieving full enteral feeds as soon as possible, with the potential benefits of reducing length of hospital stay and exposure to hospital-acquired infection, as well as enhancing brain growth. Initiation of enteral feeding was previously delayed through fears of adverse effects on the immature gut, and we did not find any systematic reviews comparing initiation in the first 24 hours with later introduction. A systematic review, which was excluded because the cut-off for early versus delayed initiation was 4 days, found no evidence of decreased risk of NEC if feeds were delayed, but did find a delay in achieving full enteral feeds. ${ }^{30}$ The definition of full enteral feeds was not consistent within and between reviews with some studies reporting milk volumes and others kilocalories consumed. Some studies specified for how long feeds were tolerated before meeting the definition. This makes direct comparisons of this outcome measure impossible.

The fetus swallows up to $250 \mathrm{~mL} / \mathrm{kg} /$ day of amniotic fluid that contains trophic factors and provides $10 \%$ of daily nutrient requirements suggesting that the newborn gut may tolerate higher fluid volumes than have been previously given. ${ }^{31}$ Faster rates of feed advancement $\left(30-40 \mathrm{~mL} / \mathrm{kg} /\right.$ day) ${ }^{22}$ and higher volumes of feeds (up to $300 \mathrm{~mL} / \mathrm{kg} /$ day $)^{24}$ had some evidence of benefit in terms of higher weight gain, shorter length of hospital stay, ${ }^{22}$ shorter time to full enteral feeds ${ }^{22}$ and reduced incidence of late-onset sepsis ${ }^{22}$ without increasing the risk of NEC. Further trials of these approaches in lowincome settings are warranted.

Multinutrient and prebiotic fortification of breast milk shows significant short-term effects but, apart from limited evidence of a lack of effect on psychomotor development at 18 months, evidence on longer term effect is lacking. Fortifying breast milk with fat alone was not shown to confer any benefit but these results were from a small study and, therefore, the evidence was limited. Fortifying feeds with fat may improve longer term outcomes, given the theoretical benefit of fats on cognition and neurodevelopment. ${ }^{32}$ Larger trials in LMIC settings, designed and powered to measure the long-term effects of breast milk fortifiers on growth and development, the incidence of adverse events as well as cost effectiveness are desirable. However, research results may not be applicable until multinutrient fortifiers become readily available and affordable in LMICs. A pragmatic alternative would be to test the effects of term formula milk powder for supplementation of calories and macronutrients with due attention to possible adverse effects.

\section{CONCLUSION}

Evidence that informs basic feeding practices of VLBW/ very preterm infants in low-resource settings in sSA is poor. There is an urgent need for trials that evaluate pragmatic, inexpensive, low technology and sustainable feeding interventions. Follow-up is needed to include longer term growth and neurodevelopmental outcomes.

Correction notice This article has been corrected since it was published. One of the author's name in the Collaborators section has been corrected.

Twitter Alison Talbert @AlisonWendyT

Acknowledgements Symon Kariuki and Kenya Medical Research Institute (KEMRI) librarian Alex Maina assisted with the search and obtaining full texts of reviews. This paper is published with the permission of the Director of the KEMRIWellcome Trust Research Programme (Kilifi Centre).

Collaborators Neonatal Nutrition Network members: Olusegun Akinyinka (College of Medicine, University of Ibadan, Nigeria); Dominic D Umoru (Maitama District Hospital, Abuja, Nigeria); Chinyere Ezeaka (Lagos University Teaching Hospital, Nigeria); Beatrice N Ezenwa (Lagos University Teaching Hospital, Nigeria); Iretiola B Fajolu (Lagos University Teaching Hospital, Nigeria); Zainab 0 Imam (Massey St. Children's Hospital, Lagos, Nigeria); Martha K Mwangome (KEMRI Wellcome Trust Research Programme, Kilifi, Kenya); Alison W Talbert (KEMRI Wellcome Trust Research Programme, Kilifi, Kenya); Pauline EA Andang'o (Maseno University, Kenya); Walter Otieno (Jaramogi Oginga Odinga Teaching and Referral Hospital, Kisumu, Kenya \& Maseno University, Kenya); Grace M Nalwa (Jaramogi Oginga Odinga Teaching and Referral Hospital, Kisumu, Kenya \& Maseno University, Kenya); Ian Sinha (Alder Hey Children's Hospital, Liverpool, UK); Janneke van de Wijgert (University of Liverpool, Liverpool, UK); Melissa Gladstone (University of Liverpool, Liverpool, UK); Kevin Mortimer (Liverpool School of Tropical Medicine, Liverpool, UK); Graham Devereux (Liverpool School of Tropical Medicine, Liverpool, UK); Ismaela Abubakar (Liverpool School of Tropical Medicine, Liverpool, UK); Stephen Turner (University of Aberdeen, Aberdeen, UK); Nicholas Embleton (Newcastle University, Newcastle, UK); Helen M Nabwera (Liverpool School of Tropical Medicine, Liverpool, UK); Stephen J Allen (Liverpool School of Tropical Medicine, Liverpool, UK); Isa Abdulkadir (Ahmadu Bello University, Zaria, Nigeria); Olukemi 0 Tongo (College of Medicine, University of Ibadan, Nigeria); Abimbola E Akindolire (College of Medicine, University of Ibadan, Nigeria).

Contributors AA conceived the study, undertook the literature search, selected reviews, extracted data and wrote the first draft of the manuscript. AT conceived the study, undertook the literature search, selected reviews, checked extracted data and wrote the first draft of the manuscript. SA conceived the study, arbitrated on selection of reviews and revised the manuscript. IS and NE advised on design of the study and revised the manuscript. All authors read and approved the final manuscript.

Funding This overview is supported by an MRC Confidence in Global Nutrition and Health Research Initiative grant: improving the survival, growth and development of low birthweight newborns through better nutrition (Reference: MC_PC_MR/ R019789/1).

Competing interests NE reports grants from Prolacta Biosciences US, grants from Danone Early Life Nutrition, personal fees from Nestle Nutrition Institute, outside the submitted work.

Patient consent for publication Not required.

Provenance and peer review Not commissioned; externally peer reviewed.

Data availability statement Data sharing not applicable as no datasets generated and/or analysed for this study. Our review analysed summary deidentified patient data from published reviews. Data availability is through the original authors of the published reviews.

Open access This is an open access article distributed in accordance with the Creative Commons Attribution 4.0 Unported (CC BY 4.0) license, which permits others to copy, redistribute, remix, transform and build upon this work for any purpose, provided the original work is properly cited, a link to the licence is given, and indication of whether changes were made. See: https://creativecommons.org/ licenses/by/4.0\%.

ORCID iDs

Alison Talbert http://orcid.org/0000-0002-9328-6903 
Nicholas Embleton http://orcid.org/0000-0003-3750-5566

\section{REFERENCES}

1 Chawanpaiboon S, Vogel JP, Moller A-B, et al. Global, regional, and national estimates of levels of preterm birth in 2014: a systematic review and modelling analysis. Lancet Glob Health 2019;7:e37-46.

2 Grandi C, González A, Zubizarreta J, et al. Perinatal factors associated with neonatal mortality in very low birth weight infants: a multicenter study. Arch Argent Pediatr 2016;114:426-33.

3 Latal-Hajnal B, von Siebenthal K, Kovari $\mathrm{H}$, et al. Postnatal growth in VLBW infants: significant association with neurodevelopmental outcome. J Pediatr 2003;143:163-70.

4 Abitbol CL, Moxey-Mims M. Chronic kidney disease: low birth weight and the global burden of kidney disease. Nat Rev Nephrol 2016;12:199-200.

5 O'Leary M, Edmond K, Floyd S, et al. A cohort study of low birth weight and health outcomes in the first year of life, Ghana. Bull World Health Organ 2017;95:574-83.

6 Cacho NT, Lawrence RM. Innate immunity and breast milk. Front Immunol 2017;8:584.

7 Lewandowski AJ, Lamata P, Francis JM, et al. Breast milk consumption in preterm neonates and cardiac shape in adulthood. Pediatrics 2016;138:e20160050.

8 Lee AC, Panchal P, Folger L, et al. Diagnostic accuracy of neonatal assessment for gestational age determination: a systematic review. Pediatrics 2017;140:e20171423.

9 World Health Organization. Guidelines on optimal feeding of low birth weight babies in low and middle income countries. Geneva: WHO, 2011.

10 Mosley WH, Chen LC. An analytical framework for the study of child survival in developing countries. 1984. Bull World Health Organ 2003;81:140-5.

11 Nyamtema AS, Urassa DP, van Roosmalen J. Maternal health interventions in resource limited countries: a systematic review of packages, impacts and factors for change. BMC Pregnancy Childbirth 2011;11:30.

12 Bradley S, McAuliffe E. Mid-level providers in emergency obstetric and newborn health care: factors affecting their performance and retention within the Malawian health system. Hum Resour Health 2009;7:14.

13 Quigley M, Embleton ND, McGuire W. Formula versus donor breast milk for feeding preterm or low birth weight infants. Cochrane Database Syst Rev 2018;6:CD002971.

14 Watson J, McGuire W. Transpyloric versus gastric tube feeding for preterm infants. Cochrane Database Syst Rev 2013;2:CD003487.

15 Tan-Dy CRY, Ohlsson A. Lactase treated feeds to promote growth and feeding tolerance in preterm infants. Cochrane Database Syst Rev 2013;3:CD004591.
16 Klenoff-Brumberg HL, Genen LH. High versus low medium chain triglyceride content of formula for promoting short term growth of preterm infants. Cochrane Database Syst Rev 2003;1:CD002777.

17 Verner A, Craig S, McGuire W. Effect of taurine supplementation on growth and development in preterm or low birth weight infants. Cochrane Database Syst Rev 2007:CD006072.

18 Shea BJ, Reeves BC, Wells G, et al. AMSTAR 2: a critical appraisal tool for systematic reviews that include randomised or nonrandomised studies of healthcare interventions, or both. BMJ 2017;358:j4008.

19 The Cochrane Collaboration. Cochrane Handbook for Systematic Reviews of Interventions Version 5.1.0 [updated March 2011], 2011.

20 Brown JVE, Embleton ND, Harding JE, et al. Multi-nutrient fortification of human milk for preterm infants. Cochrane Database Syst Rev 2016;5:CD000343.

21 Premji SS, Chessell L. Continuous nasogastric milk feeding versus intermittent bolus milk feeding for premature infants less than 1500 Grams. Cochrane Database Syst Rev 2011;11:CD001819.

22 Oddie SJ, Young L, McGuire W. Slow advancement of enteral feed volumes to prevent necrotising enterocolitis in very low birth weight infants. Cochrane Database Syst Rev 2017;8:CD001241.

23 Alshaikh B, Dharel D, Yusuf K, et al. Early total enteral feeding in stable preterm infants: a systematic review and meta-analysis. $J$ Matern Fetal Neonatal Med 2019:1-8.

24 Abiramalatha T, Thomas N, Gupta V, et al. High versus standard volume enteral feeds to promote growth in preterm or low birth weight infants. Cochrane Database Syst Rev 2017;9:CD012413.

25 Amissah EA, Brown J, Harding JE. Fat supplementation of human milk for promoting growth in preterm infants. Cochrane Database Syst Rev 2018;6:CD000341.

26 Amissah EA, Brown J, Harding JE. Carbohydrate supplementation of human milk to promote growth in preterm infants. Cochrane Database Syst Rev 2018;8:CD000280.

27 Watson J, McGuire W. Nasal versus oral route for placing feeding tubes in preterm or low birth weight infants. Cochrane Database Syst Rev 2013:CD003952.

28 Kimani-Murage EW, Wanjohi MN, Kamande EW, et al. Perceptions on donated human milk and human milk banking in Nairobi, Kenya. Matern Child Nutr 2019;15:e12842.

29 Magowan S, Burgoine K, Ogara C, et al. Exploring the barriers and facilitators to the acceptability of donor human milk in eastern Uganda - a qualitative study. Int Breastfeed J 2020;15:28.

30 Morgan J, Young L, McGuire W. Delayed introduction of progressive enteral feeds to prevent necrotising enterocolitis in very low birth weight infants. Cochrane Database Syst Rev 2014;12:CD001970.

31 Mulvihill SJ, Stone MM, Debas HT, et al. The role of amniotic fluid in fetal nutrition. J Pediatr Surg 1985;20:668-72.

32 Delplanque B, Gibson R, Koletzko B, et al. Lipid quality in infant nutrition: current knowledge and future opportunities. J Pediatr Gastroenterol Nutr 2015;61:8-17. 